\title{
New Aminophenoxazinones from a Marine Halomonas sp.: Fermentation, Structure Elucidation, and Biological Activity
}

\author{
Jens Bitzer, Thomas Große, Linzhu Wang, Siegmund Lang, Winfried Beil, Axel Zeeck
}

Received: November 16, 2005 / Accepted: January 20, 2006

(C) Japan Antibiotics Research Association

\begin{abstract}
The addition of anthranilic acid to the culture medium of the marine derived Halomonas sp. strain GWS-BW-H8hM completely altered the secondary metabolite pattern relative to the standard conditions. The red-orange color of the culture filtrate extract was the result of the production of 2-aminophenoxazin-3-one (1), chandrananimycin $\mathrm{C}(\mathbf{5})$ and three new derivatives of $\mathbf{1}$ with a previously unknown substitution pattern: 2-amino-, 2amino-8-benzoyl-, and 2-amino-8-(4-hydroxybenzoyl)-6hydroxyphenoxazin-3-one (2 4). The compounds were determined to have antibacterial and cytotoxic activities; a mode of action other than DNA intercalation is discussed.
\end{abstract}

Keywords aminophenoxazones, structure elucidation, marine bacteria, Halomonas, antibiotics

\section{Introduction}

The strain GWS-BW-H8hM belongs to the genus Halomonas and hence to the $\gamma$-proteobacteria. It was isolated from a water sample collected in the East Frisian Wadden Sea and its identification is described in related studies [1]. The strain was found to produce 3-(4'-hydroxyphenyl)-4-phenylpyrrole-2,5-dicarboxylic acid (HPPD-1), 3,4-di-(4'-hydroxy-phenyl)pyrrole-2,5dicarboxylic acid (HPPD-2) and the literature-known indole derivatives 3-(hydroxyacetyl)-indole, indole-3carboxylic acid, indole-3-carboxaldehyde, and indole-3- acetic acid. Both HPPD-1 and HPPD-2 show potent antitumor-promoting activities. Their production could be improved by optimization of the fermentation conditions [1].

Addition of anthranilic acid to the medium caused a black color of both cells and culture broth. Besides nonsoluble pigments-probably melanin- and known colorless diketopiperazines $(\mathbf{6} \sim \mathbf{1 0})$ orange-colored metabolites were produced. The latter were soluble in organic solvents and showed a typical UV absorption at $430 \mathrm{~nm}$. From the colored fraction, five 2-aminophenoxazin-3-one derivatives (1 $\sim 5$, Fig. 1) were isolated. The new metabolites $\mathbf{2}, \mathbf{3}$ and $\mathbf{4}$ exhibit a previously unknown substitution pattern of the core structure (1). The present work focuses on the production, isolation and structure elucidation of the new aminophenoxazinones and their biological activities.

$$
\begin{aligned}
& \text { 1: } \mathrm{R}^{1}=\mathrm{R}^{2}=\mathrm{H} \\
& \text { 2: } \mathrm{R}^{1}=\mathrm{OH}, \mathrm{R}^{2}=\mathrm{H} \\
& \text { 3: } \mathrm{R}^{1}=\mathrm{OH}, \mathrm{R}^{2}=\text { Benzoyl } \\
& \text { 4: } \mathrm{R}^{1}=\mathrm{OH}, \mathrm{R}^{2}=p-O H-\text { Benzoyl }
\end{aligned}
$$

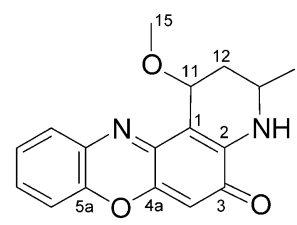

$$
5
$$

Fig. 1 Structural formulae of the isolated aminophenoxazinones 1 $\mathbf{5}$.
A. Zeeck (Corresponding author), J. Bitzer: Institute of Organic and Biomolecular Chemistry, University of Göttingen, Tammannstr. 2, D-37077 Göttingen, Germany,

E-mail: azeeck@gwdg.de
S. Lang, T. Große, L. Wang: Institute of Biochemistry and Biotechnology, Technical University of Braunschweig, Spielmannstr. 7, D-38106 Braunschweig, Germany

W. Beil: Institute of Pharmacology, Hannover Medical University, Carl-Neuberg-Str. 1, D-30625 Hannover, Germany 


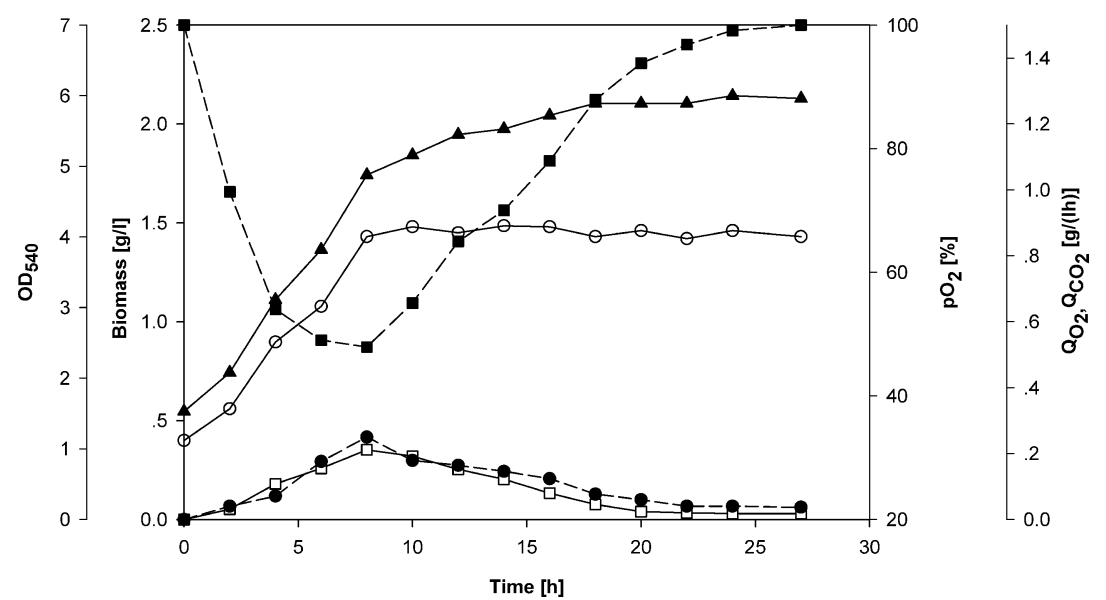

Fig. 2 Batch cultivation of Halomonas sp. strain GWS-BW-H8hM.

Data on growth (O), on oxygen partial pressure and gas balance. $\mathrm{OD}_{540}(\mathbf{\Lambda})$, optical density at $540 \mathrm{~nm}$; $\mathrm{Q}_{\mathrm{O}_{2}}(\square)$, oxygen uptake rate; $\mathrm{Q}_{\mathrm{CO}_{2}}(\bullet)$, carbon dioxide formation rate; $\mathrm{pO}_{2}(\mathbf{\square})$, oxygen partial pressure.

\section{Results}

\section{Production and Isolation}

Halomonas sp. strain GWS-BW-H8hM produces pigments, which cannot be obtained under standard conditions [1], when grown in artificial seawater containing peptone, yeast extract, and anthranilic acid as carbon and nitrogen sources.

A medium containing tryptone $1 \%$, yeast extract $0.5 \%$, glycine $0.05 \%$, and anthranilic acid $0.05 \%$ was applied in a bioreactor cultivation. Fig. 2 presents typical data of the cultivation: The maximum for biomass of $1.6 \mathrm{~g} /$ liter was reached after 8 hours. During cultivation, a significant increase of $\mathrm{OD}_{540}$ for the cell suspension was observed. Compared with the small values of biomass, this increase is due to the pigment formation, which goes parallel to the consumption of anthranilic acid. The physiological activity, indicated by the $p \mathrm{O}_{2}$ electrode data, the oxygen consumption rate $\left(\mathrm{Q}_{\mathrm{O}_{2}}\right)$, and the carbon dioxide production rate $\left(\mathrm{Q}_{\mathrm{CO}_{2}}\right)$, was connected with cell growth. From the beginning of the cultivation to 8 hours, the $\mathrm{Q}_{\mathrm{O}_{2}}$ and $\mathrm{Q}_{\mathrm{CO}_{2}}$ (maximum values with $0.2 \mathrm{~g} /($ liter hour) and $0.25 \mathrm{~g} /($ liter $\cdot$ hour $)$ ) increased significantly, while the $p \mathrm{O}_{2}$ (minimum value with $49 \%$ ) decreased during this time period. After a cultivation time of 27 hours the workup of three liters of the whole broth led to $970 \mathrm{mg}$ of a crude extract. The metabolites were isolated as shown in Fig. 3 by applying gel-chromatography with Sephadex LH-20, silica gel chromatography and preparative HPLC. The isolation resulted in $6.0 \mathrm{mg} /$ liter of $\mathbf{1}, 1.0 \mathrm{mg} /$ liter of $2,0.7 \mathrm{mg} /$ liter of $3,0.5 \mathrm{mg} /$ liter of $\mathbf{4}$ and $1.5 \mathrm{mg} /$ liter of $\mathbf{5}$. The diketopiperazines $\mathbf{6} \sim \mathbf{1 0}$ were found in yields between 0.3 and $3.0 \mathrm{mg} /$ liter. crude extract

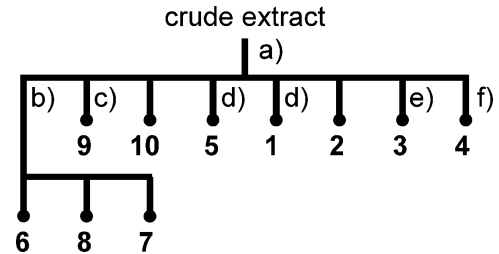

Fig. 3 Isolation scheme of the secondary metabolites from Halomonas sp. strain GWS-BW-H8hM.

a) Sephadex ${ }^{\circledR}$ LH-20, methanol; b) HPLC, Nucleodur RP-18, program 1; c) Sephadex ${ }^{\circledR}$ LH-20, acetone; d) silica gel, chloroform/ methanol $95: 5$; e) HPLC, Nucleodur RP-18, program 2; f) silica gel, cyclohexane/ethyl acetate/methanol, gradient $5: 10: 0$ to $5: 10: 1$.

\section{Structure Elucidation}

2-Aminophenoxazin-3-one (1) was identified by its characteristic UV maxima at 237, 412 and $431 \mathrm{~nm}$. The EIMS spectrum exhibited the molecular mass at $m / z=212$. Comparison of the ${ }^{1} \mathrm{H}$ and ${ }^{13} \mathrm{C}$ NMR spectra with published data $[2,3]$ proved the identity of the compound. The assignment of the ${ }^{13} \mathrm{C}$ NMR signals (Table 1) to the carbon atoms was reinvestigated and corrected. The carbonyl group $\left(\mathrm{C}-3, \delta_{\mathrm{C}}=180.1\right)$ and the carbon atom in betaposition $\left(\mathrm{C}-1, \delta_{\mathrm{C}}=98.4\right)$ were found in the typical spectral region. $\mathrm{HSQC}$ and $\mathrm{HMBC}$ correlations were used to determine the correct assignment of the other carbon atoms. The quaternary carbons $\mathrm{C}-5 \mathrm{a}\left(\delta_{\mathrm{C}}=147.3\right)$ and C-9a $\left(\delta_{\mathrm{C}}=148.2\right)$ were not distinguishable by $2 \mathrm{D}-\mathrm{NMR}$. Chemical shift calculations [4] support a more down field value for C-9a.

Compound 2 could be recognized as an aminophenoxazinone derivative by its characteristic UV spectrum, while an additional absorption maximum at 
$278 \mathrm{~nm}$ indicated small structural modifications of the chromophore. The molecular formula $\mathrm{C}_{12} \mathrm{H}_{8} \mathrm{~N}_{2} \mathrm{O}_{3}$ was determined by HRESI mass spectrometry $(\mathrm{m} / \mathrm{z}=229$ $[\mathrm{M}+\mathrm{H}]^{+}$) and suggests an additional hydroxy group compared with 1 . The ${ }^{1} \mathrm{H}$ NMR spectrum (Table 2) shows three aromatic protons in ABC-position $(J=8.0$ and $1.5 \mathrm{~Hz}$ ). Thus, the hydroxy group has to be either in position 6 or 9 of 1 . These structures could be distinguished by a detailed analysis of the ${ }^{13} \mathrm{C}$ NMR chemical shifts. A hydroxy group at C-9 would lead to a significant down field

Table $\mathbf{1}{ }^{13} \mathrm{C}$ NMR data of aminophenoxazinones $\mathbf{1} \sim \mathbf{3}$ (DMSO-d ${ }_{6}, 150 \mathrm{MHz}$; Compound 1: $75 \mathrm{MHz}$ )

\begin{tabular}{lccc}
\hline Atom & $\mathbf{1}$ & $\mathbf{2}$ & $\mathbf{3}$ \\
\hline 1 & 98.4 & 98.4 & 98.2 \\
2 & 148.8 & $148.7^{\mathrm{a}}$ & $148.8^{\mathrm{a}}$ \\
3 & 180.1 & 180.0 & 180.2 \\
4 & 103.3 & 103.0 & 103.9 \\
$4 \mathrm{a}$ & 147.3 & $147.3^{\mathrm{a}}$ & $147.6^{\mathrm{a}}$ \\
$5 \mathrm{a}$ & 141.9 & 134.8 & 134.1 \\
6 & 115.8 & 146.0 & 145.3 \\
7 & 128.7 & 115.5 & 114.9 \\
8 & 125.2 & 124.5 & $132.7^{\mathrm{b}}$ \\
9 & 127.9 & 117.4 & 120.6 \\
$9 \mathrm{a}$ & 133.7 & 131.2 & $134.0^{\mathrm{b}}$ \\
$10 \mathrm{a}$ & 148.2 & $147.8^{\mathrm{a}}$ & $148.4^{\mathrm{a}}$ \\
$1^{\prime}$ & - & - & 194.4 \\
$2^{\prime}$ & - & - & 137.1 \\
$3^{\prime} / 7^{\prime}$ & - & - & 129.3 \\
$4^{\prime} / 6^{\prime}$ & - & - & 128.5 \\
$5^{\prime}$ & - & - & 132.4 \\
\hline
\end{tabular}

${ }^{a, b}$ Assignments bearing the same superscript may be interchangeable. shift of C-5a and C-9 due to the electron withdrawing effects of O-5 and O-9, while C-9a would show a considerable up field shift because of the $+\mathrm{M}$-effect of the oxygen atoms. This was not observed; instead the data of C-9a $\left(\delta_{\mathrm{C}}=131.2\right), \mathrm{C}-5 \mathrm{a}\left(\delta_{\mathrm{C}}=134.8\right)$, and C-6 $\left(\delta_{\mathrm{C}}=146.0\right)$ (Table 1) proof the hydroxylation at $\mathrm{C}-6$. The relative up field shifts of both C-5a and C- 6 are explained by the ortho position of the oxygen atoms, so that their $-\mathrm{I}$ and $+\mathrm{M}-$ effects partially cancel out each other. In conclusion, compound 2 could be identified as 2-amino-6hydroxyphenoxazin-3-one.

With respect to compound 2, the UV spectrum of $\mathbf{3}$ changed in the area of $300 \mathrm{~nm}$ and pointed to an additional substituent at the chromophore. HRESI mass spectrometry $\left(m / z=333[\mathrm{M}+\mathrm{H}]^{+}\right)$established the molecular formula $\mathrm{C}_{19} \mathrm{H}_{12} \mathrm{~N}_{2} \mathrm{O}_{4}$. The ${ }^{13} \mathrm{C}$ NMR spectrum is similar to that of 2 but it includes the signals of an additional carbonyl group $\left(\delta_{\mathrm{C}}=194.4\right)$ and six aromatic carbons of a phenyl residue (Table 1$)$. The ${ }^{1} \mathrm{H}$ NMR spectrum shows only two aromatic protons of ring $\mathrm{C}\left({ }^{4} J_{\mathrm{HH}}=2.0 \mathrm{~Hz}\right)$, giving evidence for their meta-position (Table 2). These protons as well as those of the phenyl residue show HMBC correlations to the carbonyl group at $\delta_{\mathrm{C}}=194.4$. Consequently, compound 3 can be identified as 2-amino-8benzoyl-6-hydroxyphenoxazin-3-one.

The ${ }^{1} \mathrm{H}$ NMR spectrum of compound $\mathbf{4}$ is similar that of 3 (Table 2). However, instead of a phenyl group the spectrum exhibits two $2 \mathrm{H}$ doublets with a coupling constant of ${ }^{3} J_{\mathrm{HH}}=8.5 \mathrm{~Hz}$. Their chemical shifts $\left(\delta_{\mathrm{H}}=6.81\right.$ and 7.65$)$ indicate a para-disubstituted aromatic ring with an oxygen in para-position. HRESI mass spectrometry $(\mathrm{m} / \mathrm{z}=349$ $[\mathrm{M}+\mathrm{H}]^{+}$) confirmed the molecular formula $\mathrm{C}_{19} \mathrm{H}_{12} \mathrm{~N}_{2} \mathrm{O}_{5}$. Thus compound 4 differs from 3 by the presence of a hydroxy group and could be assigned as 2-amino-8-(4-

Table $2{ }^{1} \mathrm{H}$ NMR data of aminophenoxazinones 1 4 (DMSO- $d_{6}, 600 \mathrm{MHz}$ )

\begin{tabular}{lllll}
\hline \multicolumn{1}{c}{$\mathbf{1}$} & \multicolumn{1}{c}{$\mathbf{2}$} & \multicolumn{1}{c}{$\mathbf{3}$} & \multicolumn{1}{c}{$\mathbf{4}$} \\
\hline 1 & $6.34, \mathrm{~s}$ & $6.31, \mathrm{~s}$ & $6.36, \mathrm{~s}$ & $6.34, \mathrm{~s}$ \\
4 & $6.37, \mathrm{~s}$ & $6.37, \mathrm{~s}$ & $6.41, \mathrm{~s}$ & $6.37, \mathrm{~s}$ \\
6 & $7.48, \mathrm{dd}(8.0,1.5)$ & - & - & - \\
7 & $7.45, \mathrm{td}(8.0,1.5)$ & $6.99, \mathrm{dd}(8.0,1.5)$ & $7.38, \mathrm{~d}(2.0)$ & $7.30^{\mathrm{a}}, \mathrm{m}$ \\
8 & $7.38, \mathrm{td}(8.0,1.5)$ & $7.15, \mathrm{t}(8.0)$ & - & - \\
9 & $7.69, \mathrm{dd}(8.0,1.5)$ & $7.10, \mathrm{dd}(8.0,1.5)$ & $7.42, \mathrm{~d}(2.0)$ & $7.23^{\mathrm{a}}, \mathrm{d}(2.0)$ \\
$\mathrm{NH}_{2}$ & $6.76, \mathrm{br} \mathrm{s}$ & $6.69, \mathrm{br} \mathrm{s}$ & $6.88, \mathrm{br} \mathrm{s}$ & $6.73, \mathrm{br} \mathrm{s}$ \\
$3^{\prime} / 7^{\prime}$ & - & - & $7.76, \mathrm{~d}(7.5)$ & $7.74, \mathrm{~d}(9.0)$ \\
$4^{\prime} / 6^{\prime}$ & - & - & $7.59, \mathrm{t}(7.5)$ & $6.85, \mathrm{~d}(9.0)$ \\
$5^{\prime}$ & - & - & $7.69, \mathrm{t}(7.5)$ & - \\
\hline
\end{tabular}

a assignments may be interchangeable. 
hydroxybenzoyl)-6-hydroxyphenoxazin-3-one.

The compound of fraction 4 (EI-MS: $m / z=296)$ was identified as chandrananimycin $\mathrm{C}$ (5) by comparison of the NMR data given in the literature [3].

In the more lipophilic fractions $1 \sim 3$ of the crude extract (Fig. 3), five proline-containing diketopiperazines were found as metabolites of Halomonas sp. The structures of cyclo(prolylvalyl) (6), cyclo(leucylprolyl) (7), cyclo(isoleucylprolyl) (8), cyclo(phenylalanylprolyl) (9), and cyclo(prolyltyrosyl) (10) (Fig. 4) were elucidated by comparison of their ${ }^{1} \mathrm{H}$ NMR and EI-MS spectra with published data $[5,6]$. Diketopiperazines are produced by condensation of two amino acids and are widespread as metabolites of various bacteria and fungi. Natural diketopiperazines show a remarkably preference for proline as a building block [7]. They consist mostly of two L-amino acids, but DL-, LD-, and DD-isomers can be generated by non-enzymatic epimerization, possibly accelerated by neighboring groups [8].<smiles>[R]C1NC(=O)C2CCCN2C1=O</smiles>

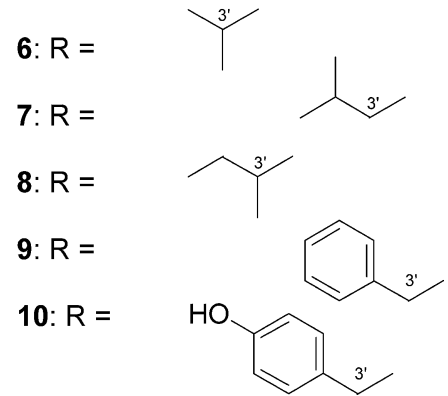

Fig. 4 Structural formulae of the isolated diketopiperazines $\mathbf{6} \sim \mathbf{1 0}$.

\section{Biological Activity}

The aminophenoxazinones $\mathbf{1} \sim \mathbf{5}$ were tested against different bacteria and Candida albicans in a plate diffusion assay (Table 3). The strongest growth inhibition of Grampositive bacteria was observed for compound $\mathbf{2}$. The core structure itself (compound 1) as well as the more lipophilic derivative $\mathbf{3}$ had weaker activities. The experimental compounds were significantly less potent than the reference compound, actinomycin D. No antimicrobial activity was observed for compounds $\mathbf{4}$ and 5; the latter result is in contrast to previous reports [3]. Aminophenoxazinone 1 was the only metabolite that exhibited activity against $C$. albicans.

Compounds 1, $\mathbf{2}$ and $\mathbf{3}$ are moderately cytotoxic against different tumor cell lines (Table 4). The effect of actinomycin D is about 2 to 3 orders of magnitude higher. Compound $\mathbf{1}$ with the aminophenoxazinone core structure exhibited a stronger cytotoxicity than the derivatives of $\mathbf{1}$. The results of a cell cycle analysis of $\mathbf{1}$ are given in Table 5 .

Table 3 Antimicrobial activity of the aminophenoxazinones $\mathbf{1} \sim \mathbf{3}$ and actinomycin $\mathrm{D}$ in a plate diffusion assay

\begin{tabular}{ccccc}
\hline Test organism & E. coli & B. subtilis & S. aureus & C. albicans \\
\hline $\mathbf{1}$ & 0 & 20 & 15 & 25 \\
$\mathbf{2}$ & 0 & 25 & 16 & 0 \\
$\mathbf{3}$ & 0 & 16 & 10 & 0 \\
Actinomycin D & 16 & 35 & 25 & 0 \\
\hline
\end{tabular}

Diameter of the inhibition zones in $\mathrm{mm}, 50 \mu \mathrm{g}$ of compound on $6 \mathrm{~mm}$ filter discs.

Table 4 Cytotoxicities of the aminophenoxazinones $\mathbf{1} \sim \mathbf{3}$ against different tumor cell lines: HM02 (gastric adenocarcinoma), HepG2 (hepatocellular carcinoma) and MCF7 (breast adenocarcinoma) $\left(\mathrm{GI}_{50}\right.$ and $\mathrm{TGI}$ values in $\left.\mu \mathrm{g} / \mathrm{ml}\right)$

\begin{tabular}{|c|c|c|c|c|c|c|}
\hline \multirow{2}{*}{ Cell line } & \multicolumn{2}{|c|}{ HM02 } & \multicolumn{2}{|c|}{ HepG2 } & \multicolumn{2}{|c|}{ MCF7 } \\
\hline & $\mathrm{GI}_{50}$ & TGI & $\mathrm{G}_{150}$ & TGI & $\mathrm{Gl}_{50}$ & TGI \\
\hline 1 & 0.95 & 2.2 & 1.4 & 5.6 & 0.13 & 0.42 \\
\hline 2 & 1.6 & 2.6 & 4.3 & $>10$ & 1.6 & 2.7 \\
\hline 3 & 1.4 & 2.6 & 3.2 & 10 & 2.0 & 3.2 \\
\hline Actinomycin D & 0.002 & 0.008 & 0.0015 & 0.0065 & 0.0024 & 0.011 \\
\hline
\end{tabular}

$\mathrm{GI}_{50}$ is the concentration at which half of the cells were inhibited in their growth, and TGI is the concentration at which a total inhibition of cell growth was observed. 
Table 5 Cell cycle investigation with $\mathrm{HMO} 2$ cells (\% cells in the specified cell phase \pm standard deviation).

\begin{tabular}{lcccc}
\hline Cell phase & $\begin{array}{c}\text { Sub G1 } \\
\text { (apoptose) }\end{array}$ & G0/G1 & S & G2/M \\
\hline Control & $3.6 \pm 1.3$ & $54.5 \pm 3.5$ & $19.7 \pm 0.8$ & $21.5 \pm 5$ \\
$\mathbf{1}$ & $20 \pm 11$ & $34 \pm 5^{*}$ & $21.5 \pm 6$ & $22.7 \pm 0.4$ \\
Actinomycin D & $6.0 \pm 3.4$ & $54.0 \pm 6.5$ & $10.0 \pm 1.6^{*}$ & $29.2 \pm 8.5$ \\
\hline
\end{tabular}

${ }^{*} p<0.05$ versus control ( $t$-test)

\section{Discussion}

The addition of anthranilic acid to the culture medium of Halomonas sp. (strain GWS-BW-H8hM) changes the metabolite pattern completely and leads to the production of five aminophenoxazinones. Thus, the manipulation of this marine strain is a good example for the OSMAC (one strain - many compounds) approach [9] to the production of novel secondary metabolites. The core structure 2aminophenoxazin-3-one (1) is the main product and known to originate biosynthetically from an oxidative coupling of two units of anthranilic acid [10]. 1 can undergo a regioselective hydroxylation at C-6 to form $\mathbf{2}$. Furthermore, an acylation of $\mathbf{2}$ with a benzoyl or 4-hydroxybenzoyl residue at $\mathrm{C}-8$ can be assumed. These groups may be derived from phenylalanine and tyrosine, respectively.

Compound $\mathbf{2}$ is the first-known aminophenoxazinone derivative substituted at C-6 only. The 6,8-disubstituted compounds 3 and $\mathbf{4}$ as well represent a previously unknown substitution pattern. In all other known aminophenoxazinones, a residue in position 6 is always accompanied with a second substitution at position 9. This pattern is known for instance from the actinomycins, cytotoxic chromopeptides with an aminophenoxazinone chromophore [11].

Unexpectedly, 2-amino-6-hydroxyphenoxazin-3-one (2) exhibited a higher antibacterial activity than the core structure 1. Assuming a mode of action based on intercalation with the DNA double helix, any modifications at the chromophore should weaken the interaction, and consequently the antibacterial activity. The opposite effect could be the result of a different mode-of-action, which is supported by cell cycle investigations with HM02 cells (Table 5). Actinomycin D reduces significantly the ratio of cells in the S-phase, as expected for an intercalating DNA inhibitor [12]. In contrast, 2-aminophenoxazin-3-one (1) reduces the ratio of cells in the resting phases $(\mathrm{G} 0 / \mathrm{G} 1)$ and forces the cells directly to apoptosis. These experiments demonstrate that $\mathbf{1}$ represses the cells' transition from the resting phase to the synthesis phase and hence induces programmed cell death.

\section{Experimental}

\section{General}

NMR spectra were recorded on Varian Inova 600 and Unity 300 spectrometers. Chemical shifts are expressed in $\delta$ values using the solvent as internal standard (DMSO- $d_{6}: \delta_{\mathrm{H}}$ $\left.2.50, \quad \delta_{\mathrm{C}} 39.5 ; \mathrm{CDCl}_{3}: \delta_{\mathrm{H}} 7.25, \delta_{\mathrm{C}} 77.0\right)$. Coupling constants are given in Hz. EI mass spectra were recorded on Finnigan MAT $95(70 \mathrm{eV})$; relative intensities in parenthesis refer to the highest peak of the spectrum. ESIMS spectra were obtained on Finnigan LC-Q and HRESIMS spectra on Bruker Apex-Q III (field strength 7 Tesla). Infrared spectra were recorded on a Perkin-Elmer model 1600 as $\mathrm{KBr}$ pellets. UV spectra were obtained in methanol on a Varian Cary 3E spectrometer.

\section{Fermentation and Growth}

Initial growth of Halomonas sp. GWS-BW-H8hM was achieved on Marine Broth 2216 (Difco, Germany). Slants were stored at $4{ }^{\circ} \mathrm{C}$ and transferred on monthly intervals. Liquid cultures $(1000 \mathrm{ml}$ and $2000 \mathrm{ml}$ Erlenmeyer flasks, using $250 \mathrm{ml}$ and $500 \mathrm{ml}$ broth volumes, respectively) were incubated at $27^{\circ} \mathrm{C}$ in a shake-incubator rotating at $100 \mathrm{rpm}$ for 72 hours. The artificial seawater medium contained per liter: Fe citrate $0.1 \mathrm{~g}, \mathrm{NaCl} 19.45 \mathrm{~g}, \mathrm{MgCl}_{2} \cdot 6 \mathrm{H}_{2} \mathrm{O} 8.8 \mathrm{~g}$, $\mathrm{Na}_{2} \mathrm{SO}_{4} 3.24 \mathrm{~g}, \mathrm{CaCl}_{2} \cdot 2 \mathrm{H}_{2} \mathrm{O} 2.38 \mathrm{~g}, \mathrm{Na}_{2} \mathrm{HPO}_{4} 0.01 \mathrm{~g}, \mathrm{SiO}_{2}$ $0.015 \mathrm{~g}$, trace elements [13] $1 \mathrm{ml}$, stock solution for artificial seawater $10 \mathrm{ml}$. The optimized medium contained the following supplements: tryptone $10 \mathrm{~g}$, yeast extract $5 \mathrm{~g}$, glycine $0.5 \mathrm{~g}$, and anthranilic acid $0.5 \mathrm{~g}$ in 1 liter. For a batch cultivation in artificial seawater medium a 30-liter bioreactor (Biostat P, Braun Diessel, Melsungen, Germany) was used with the following conditions: 20 liters working volume, inoculation with $10 \%(\mathrm{v} / \mathrm{v})$ of a 24-hour 
preculture; temperature $27^{\circ} \mathrm{C}$, stirring at $250 \mathrm{rpm}$, aeration rate $0.1 \mathrm{v} / \mathrm{vm}, \mathrm{pH}$ adjusted to 7.5 . The bioreactor was equipped with a six-bladed disc turbine, and the physiological activity was followed by the use of a $p \mathrm{O}_{2}$ electrode, and by oxygen and carbon dioxide gas analyzers (Oxygor and Unor, Maihak, Hamburg, Germany). For biomass measurements, $20 \mathrm{ml}$ of cell culture were centrifuged for 30 minutes at $13,000 \mathrm{rpm}$ and at $4^{\circ} \mathrm{C}$. After drying at $105^{\circ} \mathrm{C}$, the biomass was determined gravimetrically.

\section{Isolation}

The $\mathrm{pH}$ value of three liters of whole broth was adjusted to $\mathrm{pH} 3.0(\mathrm{HCl})$. After extraction with six liters ethyl acetate, the solvent was evaporated at 240 mbar and by brief freezedrying. The products were purified as shown in Fig. 3 . Silica gel $60 \quad(0.2 \sim 0.05 \mathrm{~mm}$, Macherey-Nagel $)$ and Sephadex ${ }^{\circledR}$ LH-20 (Sigma Aldrich) were used for column chromatography. Preparative high performance liquid chromatography: Jasco PU-1587 pump; Jasco UV-1575 UV-detector; Rheodyne manual injection valve; software Jasco Borwin ${ }^{\mathrm{TM}}$ Version 1.50 with Jasco HSS-2000 Version 3.5.2; column Jasco Nucleosil $100 \mathrm{C} 18,5 \mu \mathrm{m}$, $250 \times 8 \mathrm{~mm}$, flow rate $2.6 \mathrm{ml} /$ minute; solvent system: water (A)/acetonitrile (B), both with $0.1 \%$ TFA; program 1 : 13 minutes at $17 \% \mathrm{~B}$, in 1.5 minutes to $90 \% \mathrm{~B}, 5$ minutes at $90 \% \mathrm{~B}$, in 1.5 minutes to $17 \% \mathrm{~B}, 2$ minutes at $17 \% \mathrm{~B}$, UV-detection at $215 \mathrm{~nm}$; program 2: 7 minutes at $22 \% \mathrm{~B}$, in 1 minute to $44 \%$ B, 10 minutes at $44 \%$ B, in 1 minute to $88 \% \mathrm{~B}, 5$ minutes at $88 \% \mathrm{~B}$, in 2 minutes to $22 \% \mathrm{~B}, 2$ minutes at $22 \% \mathrm{~B}, \mathrm{UV}$-detection at $254 \mathrm{~nm}$.

\section{Biological Tests}

For plate diffusion tests $50 \mu \mathrm{g}$ of the desired compound were solved in methanol and dropped on paper disks (diameter $6 \mathrm{~mm}$, thickness $0.5 \mathrm{~mm}$ ). These were dried under sterile conditions and put on agar plates inoculated with the test organism (Bacillus subtilis, Staphylococcus aureus, Escherichia coli, and Candida albicans). The plates were cultivated at $37^{\circ} \mathrm{C}$ (bacteria) or $25^{\circ} \mathrm{C}$ (yeast) for 24 hours.

The cytotoxic activity was determined according to the NCI (USA) protocol [14] with the tumor cell lines HM02 (gastric adenocarcinoma), HepG2 (hepatocellular carcinoma) and MCF7 (breast adenocarcinoma). The cells were cultivated in 96-well micro titer plates with medium RPMI 1640 with $10 \%$ fetal bovine serum. After 24 hours the test compounds were added as DMSO solutions $(c=0.001,0.005,0.01,0.05,0.1,0.5,1$ and $10 \mu \mathrm{g} / \mathrm{ml})$ and the cells cultivated for additional 48 hours. The cell count was surveyed by protein determination with sulforhodamin. From the resulting concentration-activity curves, the $\mathrm{GI}_{50}$ (concentration at which half of the cells were inhibited in their growth) and TGI values (concentration at which a total inhibition of cell growth was observed) were obtained.

Cell cycle distributions were determined with HM02 cells that were incubated for 24 hours in 12-well plates with RPMI 1640 with $10 \%$ fetal bovine serum. After addition of the test compound as DMSO solution $(10 \mu \mathrm{g} / \mathrm{ml})$ the cells were cultivated for another 24 hours. The supernatant was taken off and the cells washed with $300 \mu$ lice cold PBS solution. The PBS solution was transferred in $4.4 \mathrm{ml} 100 \%$ ethanol (ice cooled). The adherend cells were incubated with $300 \mu \mathrm{l}$ trypsin solution $\left(37^{\circ} \mathrm{C}\right)$. After 2 minutes the supernatant was added $(1 \mathrm{ml})$ and the cell suspension $(1.3 \mathrm{ml})$ repeatedly soaked up with a pipette before it was transferred in the ethanol solution. The cell suspension was stored for 30 minutes on ice and afterwards centrifuged at $3000 \mathrm{rpm}$. The supernatant was discarded, the pellet resuspended in $0.5 \mathrm{ml}$ PBS solution with $1 \%$ BSA and centrifuged at $4500 \mathrm{rpm}$ for 5 minutes. The supernatant was taken off and the pellet solved in $100 \mu \mathrm{l}$ staining solution (propidium bromide $150 \mu \mathrm{g} / \mathrm{ml}, 4 \mathrm{mM} \mathrm{Na}$ citrate $\mathrm{pH} 7.0$, Triton C-100 1\%, BSA 1\%). After 15 minutes incubation at room temperature in the dark, $100 \mu \mathrm{l}$ RNAse solution $(10 \mathrm{mg} / \mathrm{ml}$ Ribonuclease A in Tris/ $\mathrm{HCl}$ buffer, $\mathrm{pH} 7.5)$ were added. Thirty minutes later the cell suspension was counted by FACSscan.

\section{2-Aminophenoxazin-3-one (1)}

Red solid; Rf $0.54\left(\mathrm{CH}_{3} \mathrm{Cl} / \mathrm{MeOH}, 9: 1\right)$; EI-MS $(70 \mathrm{eV})$ $m / z(\%) 212(100)\left[\mathrm{M}, \mathrm{C}_{12} \mathrm{H}_{8} \mathrm{~N}_{2} \mathrm{O}_{2}\right]^{+}, 185$ (35); UV $\lambda_{\max }^{\mathrm{MeOH}}$ $\mathrm{nm}(\log \varepsilon) 237$ (4.34), 421 (4.26), 431 (4.26); IR $\tilde{v}_{\max }$ $(\mathrm{KBr}) \mathrm{cm}^{-1} 3407,1580,1472,1420,1278,1176,1106$, 1054; ${ }^{1} \mathrm{H}$ NMR $\left(600 \mathrm{MHz}, \mathrm{DMSO}-d_{6}\right)$ see Table $2 ;{ }^{13} \mathrm{C}$ NMR (75.5 MHz, DMSO- $d_{6}$ ) see Table 1.

\section{2-Amino-6-hydroxyphenoxazin-3-one (2)}

Red solid; Rf $0.43\left(\mathrm{CH}_{3} \mathrm{Cl} / \mathrm{MeOH}, 9: 1\right)$; EI-MS (70 eV) $m / z(\%) 228$ (100) [M, $\left.\mathrm{C}_{12} \mathrm{H}_{8} \mathrm{~N}_{2} \mathrm{O}_{3}\right]^{+}, 201$ (40); HRESI-MS calcd $m / z 229.06077[\mathrm{M}+\mathrm{H}]^{+}$, found $m / z$ 229.06079; UV $\lambda_{\max }^{\mathrm{MeOH}} \mathrm{nm}(\log \varepsilon) 236$ (3.93), 277 (3.75), 430 (3.72); IR $\tilde{v}_{\max }$ $(\mathrm{KBr}) \mathrm{cm}^{-1} 3431,1643(\mathrm{sh}), 1589,1506,1460,1382$, $1277,1212,1085,1027 ;{ }^{1} \mathrm{H}$ NMR (600 MHz, DMSO- $d_{6}$ ) see Table $2 ;{ }^{13} \mathrm{C}$ NMR $\left(150 \mathrm{MHz}\right.$, DMSO- $\left.d_{6}\right)$ see Table 1.

\section{2-Amino-8-benzoyl-6-hydroxyphenoxazin-3-one (3)}

Red solid; Rf $0.49\left(\mathrm{CH}_{3} \mathrm{Cl} / \mathrm{MeOH}, 9: 1\right)$; ESI-MS $m / z$ pos. $333\left[\mathrm{M}+\mathrm{H}, \mathrm{C}_{19} \mathrm{H}_{13} \mathrm{~N}_{2} \mathrm{O}_{4}\right]^{+}, 687[2 \mathrm{M}+\mathrm{Na}]^{+}$; neg. 331 $[\mathrm{M}-\mathrm{H}]^{-}, \quad 663 \quad[2 \mathrm{M}-\mathrm{H}]^{-}$; HRESI-MS calcd $\mathrm{m} / \mathrm{z}$ $333.086983[\mathrm{M}+\mathrm{H}]^{+}$, found $m / z$ 333.086901; UV $\lambda_{\max }^{\mathrm{MeOH}}$ nm $(\log \varepsilon) 257$ (3.81), 309 (3.59), 432 (3.46); IR $\tilde{v}_{\max }$ $(\mathrm{KBr}) \mathrm{cm}^{-1} 3435,2943,2361,1670,1638,1432,1264$, 
1202, 1137, 1088, 1034; ${ }^{1} \mathrm{H}$ NMR (600 MHz, DMSO- $\left.d_{6}\right)$ see Table $2 ;{ }^{13} \mathrm{C}$ NMR $\left(150 \mathrm{MHz}\right.$, DMSO- $\left.d_{6}\right)$ see Table 1 .

\section{2-Amino-8-(4-hydroxybenzoyl)-6-hydroxyphenoxazin-3- one (4)}

Red solid; Rf $0.32\left(\mathrm{CH}_{3} \mathrm{Cl} / \mathrm{MeOH}, 9: 1\right)$; ESI-MS $m / z$ pos. $349\left[\mathrm{M}+\mathrm{H}, \mathrm{C}_{19} \mathrm{H}_{13} \mathrm{~N}_{2} \mathrm{O}_{5}\right]^{+}, 719[2 \mathrm{M}+\mathrm{Na}]^{+}$; neg. 347 $[\mathrm{M}-\mathrm{H}]^{-}, 695[2 \mathrm{M}-\mathrm{H}]^{-}$; HRESI-MS calcd $\mathrm{m} / z 349.08190$ $[\mathrm{M}+\mathrm{H}]^{+}$, found $m / z$ 349.08176; UV $\lambda_{\max }^{\mathrm{MeOH}} \mathrm{nm}(\log \varepsilon) 266$ (3.54), 300 (3.52), 428 (3.44), 434 (3.45); IR $\tilde{v}_{\max }(\mathrm{KBr})$ $\mathrm{cm}^{-1} 3432,1618,1584,1398,1265,1176,1109,1029 ;{ }^{1} \mathrm{H}$ NMR $\left(600 \mathrm{MHz}, \mathrm{DMSO}-d_{6}\right)$ see Table 2.

\section{Chandrananimycin C (5)}

Red solid; Rf $0.78\left(\mathrm{CH}_{3} \mathrm{Cl} / \mathrm{MeOH}, 9\right.$ : 1); EI-MS $(70 \mathrm{eV})$ $m / z(\%) 296(42)\left[\mathrm{M}, \mathrm{C}_{17} \mathrm{H}_{16} \mathrm{~N}_{2} \mathrm{O}_{3}\right]^{+}, 281$ (20), 266 (100), 265 (56), 264 (50), 263 (42), 250 (27), 249 (100), 238 (20), 221 (36); ${ }^{1} \mathrm{H}$ NMR $\left(300 \mathrm{MHz}, \mathrm{CDCl}_{3}\right) \delta 1.36(\mathrm{~m}, 1 \mathrm{H}, 12-$ $\left.\mathrm{H}_{\mathrm{a}}\right), 1.37\left(\mathrm{~d}, J=6.5 \mathrm{~Hz}, 3 \mathrm{H}, 14-\mathrm{H}_{3}\right), 2.22\left(\mathrm{~m}, 1 \mathrm{H}, 12-\mathrm{H}_{\mathrm{b}}\right)$, 3.53 (s, 3H, OMe), $3.73(\mathrm{~m}, 1 \mathrm{H}, 13-\mathrm{H}), 5.07$ (t, $J=3.0 \mathrm{~Hz}$, $1 \mathrm{H}, 11-\mathrm{H}), 5.88$ (br s, 1H, NH), $6.35(\mathrm{~s}, 1 \mathrm{H}, 4-\mathrm{H}), 7.35$ (m, $3 \mathrm{H}, 6-\mathrm{H}, 7-\mathrm{H}, 8-\mathrm{H}), 7.76$ (dt, $J=7.0,1.5 \mathrm{~Hz}, 1 \mathrm{H}, 9-\mathrm{H})$.

Acknowledgement The authors would like to thank Prof. Dr. M. Simon and Dr. H. Stevens (Institute for Chemistry and Biology of the Marine Environment, University of Oldenburg, Germany) for providing us with the strain Halomonas sp. GWS-BW-H8hM. This work was supported by the Volkswagen Foundation within the Lower Saxonian priority program 'Marine Biotechnology'.

\section{References}

1. Wang L, Große T, Stevens H, Brinkhoff T, Simon M, Liang L, Bitzer J, Bach G, Zeeck A, Tokuda H, Lang S. Bioactive hydroxyphenylpyrrole-dicarboxylic acids from a new marine Halomonas sp.: Production and structure elucidation. Appl Microbiol Biotechnol In press

2. Hasegawa K, Ueno Y. The carbon-13 NMR spectra and electronic structure of 3H-phenoxazin-3-ones. Bull Chem Soc Jpn 58: 2832-2839 (1985)
3. Maskey RP, Li FC, Qin S, Fiebig HH, Laatsch $\mathrm{H}$. Chandrananimycins $\mathrm{A} \sim \mathrm{C}$ : Production of novel anticancer antibiotics from a marine Actinomadura sp. isolate M048 by variation of medium composition and growth conditions. J Antibiot 56: 622-629 (2003)

4. ACD/CNMR Predictor, Version 6.12. Advanced Chemistry Development Inc., Toronto (2002)

5. Fdhila F, Vazquez V, Sánchez JL, Riguera R. DDDiketopiperazines: Antibiotics active against Vibrio anguillarum isolated from marine bacteria associated with cultures of Pecten maximus. J Nat Prod 66: 1299-1301 (2003)

6. De-hai L, Quian-qun G, Wei-ming Z, Hong-bing L, Yu-chun F, Tian-jiao Z. Antitumor components from marine actinomycete 11014. I. Cyclic dipeptides. Chin J Antibiot 30: 449-452 (2005)

7. Bull SD, Davies SG, Parkin RM, Sánchez-Sancho F. The biosynthetic origin of diketopiperazines derived from Dproline. J Chem Soc, Perkin Trans 1 2313-2320 (1998)

8. Smith GG, Evans RC, Baum R. Neighboring residue effects: Evidence for intramolecular assistance to racemization or epimerization of dipeptide residues. J Am Chem Soc 108: 7327-7332 (1986)

9. Bode HB, Bethe B, Höfs R, Zeeck A. Big effects from small changes: Possible ways to explore nature's chemical diversity. ChemBioChem 3: 619-627 (2002)

10. Barry CE, Nayar PG, Begley TP. Phenoxazinone synthase: Mechanism for the formation of the phenoxazinone chromophore of actinomycin. Biochemistry 28: 6323-6333 (1989)

11. Mauger AB, Lackner H. The Actinomycins. In Anticancer agents from natural products. Eds. Kingston DGI, Cragg GM \& Newman DJ, pp. 281-298, CRC Press, Boca Raton (2005)

12. Wu MH, Yung BY. Cell cycle phase-dependent cytotoxicity of actinomycin D in HeLa cells. Eur J Pharmacol 270: 203212 (1994)

13. Hoagland $\mathrm{H}$. Quantitative analysis of responses from lateraline nerves of fishes. J Gen Physiol 16: 715-732 (1933)

14. Grever MR, Schepartz SA, Chabner BA. The National Cancer Institute: Cancer drug discovery and development program. Semin Oncol 19: 622-638 (1992) 